\title{
Optimization of milling speed and time in mechanical alloying of ferritic ODS steel through taguchi technique
}

\author{
Ganesan Dharmalingam(D), Murali Arun Prasad, and Sachin Salunkhe* (D) \\ Department of Mechanical Engineering, Vel Tech Rangarajan Dr. Sagunthala R\&D Institute of Science and Technology, Avadi, \\ Chennai 600 062, Tamil Nadu, India
}

Received: 16 August 2021 / Accepted: 14 October 2021

\begin{abstract}
The oxide dispersion strengthened (ODS) ferritic steels are one of the most important in fuel cladding materials for 4th Generation nuclear reactors because of their excellent mechanical properties such as irradiation resistance, swelling resistance, and elevated temperature tensile/compressive strength. Mechanical alloying (MA) is one of the most promising routes for developing nanocrystalline ferritic ODS steel materials. For the production of nanocrystalline ferritic ODS steel powders, the most influencing factor is the milling speed and milling time during the mechanical alloying process. With the improper selection of milling time and speed, the final milled powders become an amorphous structure consisting of high impurity inclusions in the microstructure, and strength was also affected. In order to overcome these drawbacks, the present investigation was taken into account for the selection of appropriate mechanical milling speed and time, which was optimized through Taguchi analysis followed by the MA process. The optimized mechanical milling speed and time of milled powders were characterized through X-Ray Diffraction Analysis (XRD) and Scanning Electron Microscope (SEM).
\end{abstract}

Keywords: Mechanical alloying / mechanical milling process / taguchi analysis / XRD / SEM

\section{Introduction}

Ferritic oxide dispersion strengthened (ODS) steels have been motivated for the generation IV fusion, fission nuclear reactors for resisting the harsh environments. It is also used for resisting the high operating temperatures in nuclear reactors. Because this ODS steels have excellent swelling resistance, irradiation resistance, oxidation resistance, and room/high temperature tensile/compressive strength than other austenitic stainless steel. The powder metallurgy $(\mathrm{P} / \mathrm{M})$ route is used to produce the ODS steels powders, followed by the mechanical alloying process [1-3]. To achieve superior mechanical properties at elevated temperature, the most influencing factor is finely dispersed nano oxide particles and the high density in the homogeneous grain matrix with unique microstructure, which was important for the ODS steel. These can be achieved through the mechanical alloying (MA) process followed by the high-energy planetary ball milling method $[4,5]$. The mechanical alloying will determine the powder properties such as crystallite size, particle size, homogeneity, and purity.

\footnotetext{
* e-mail: drsalunkhesachin@veltech.edu.in
}

These will improve the mechanical properties and microstructure of ODS steel [6,7]. For the research purpose, one of the most suitable and commonly used is planetary ball milling to perform the MA experiment inside a pulversette high energy planetary ball milling because it can also be milled at a time with few grams powders compared to other ball milling methods $[7,8]$. The milling time and milling speed are the most important parameters during the ball milling process parameter selection. The selected milling time should achieve a steady-state between the cold welding and the fracturing of powder particles [9]. Milling time should be fixed based on the ball to powder weight ratio, type of mill used, and milling temperature $[3,10]$. Suryanarayana reported that a longer milling time could produce undesirable phases and the contamination of powders during the mechanical alloying [11]. The higher milling speed does not generate the required impact force; as a result, that proper milling did not occur during the MA. During the milling, the maximum milling speed is always below the critical milling speed so that the balls will go to maximum height [12]. High impact energy is generated between the balls and the powders. Because of that collision, it could encourage the alloying of the powders during the mechanical ball milling [13]. 
Table 1. Composition of ferritic stainless steel and its mixture.

\begin{tabular}{|c|c|c|c|c|c|c|c|c|}
\hline \multirow[t]{2}{*}{ Materials grade } & $\underline{\mathrm{Cr}}$ & $\underline{\mathrm{Mn}}$ & $\underline{\mathrm{Si}}$ & $\underline{\mathrm{C}}$ & $\underline{\mathrm{P}}$ & $\underline{\mathrm{S}}$ & $\underline{\mathrm{Fe}}$ & \multirow[t]{2}{*}{ Hypothetical density $(\mathrm{g} / \mathrm{cc})$} \\
\hline & \multicolumn{7}{|c|}{ All are in percentage of weight ( $\mathrm{wt} \%)$} & \\
\hline $430 \mathrm{~L}$ & 17 & 0.89 & 0.8 & 0.02 & 0.0 & 0.01 & Balance & 7.70 \\
\hline Alloy & \multicolumn{7}{|c|}{$\left(430 \mathrm{~L}+0.3 \mathrm{Y}_{2} \mathrm{O}_{3}+0.5 \mathrm{ZrO}_{2}+0.1 \mathrm{Ti}+1 \mathrm{~W}\right) \mathrm{wt} \%$} & 7.78 \\
\hline
\end{tabular}

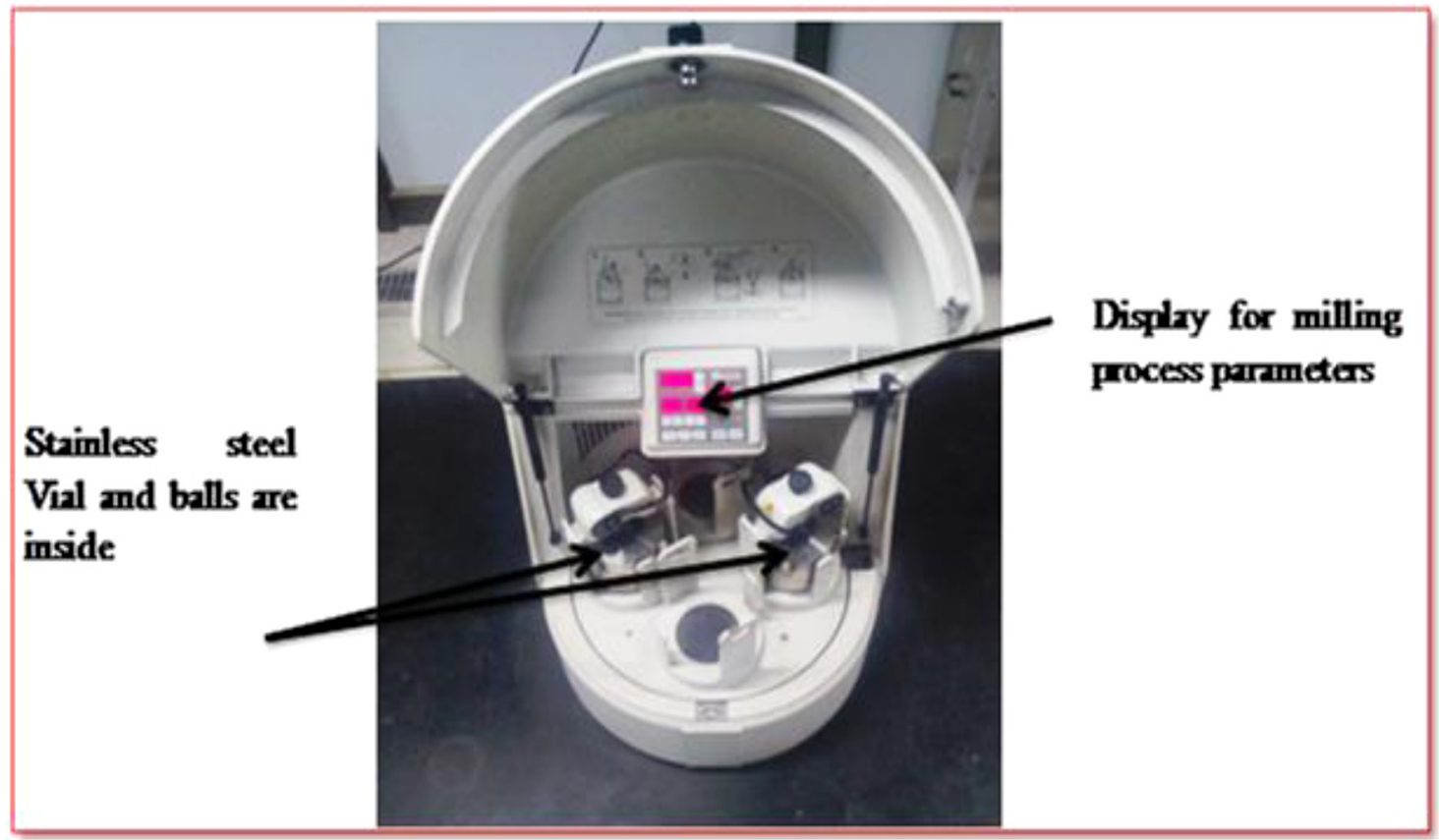

Fig. 1. High energy planetary ball milling machine.

Based on the above-mentioned literature survey the many of the researchers used different milling times and speeds of the ODS steel, but none of the researchers reported the optimized milling speed and time of the ferritic ODS steel. In order to select the appropriate milling speed and time of the ferritic ODS steel, the Taguchi analysis and analysis of variance (ANOVA) was utilized in the present study.

\section{Experimental details}

The 430L ferritic stainless steel initial powder $(99.9999 \%$ purity, $22 \mu \mathrm{m}$ ) was purchased from SANDVIK Company. The chemical composition of ferritic stainless-steel powder is shown in Table 1 . The $430 \mathrm{~L}$ powders are mixed to yield an alloy with a composition of $430 \mathrm{~L}+0.3 \mathrm{Y}_{2} \mathrm{O}_{3}+$ $0.5 \mathrm{ZrO}_{2}+0.1 \mathrm{Ti}+1 \mathrm{~W}$ in weight percentage. The mechanical alloying equipment is used as a high-energy planetary ball mill with a stainless-steel vessel and balls $(\phi 10 \mathrm{~mm})$, as shown in Figure 1 for the present study. The mechanical alloying has constant process parameters such as a ball to powder weight ratio of $10: 1$, toluene medium to control the exothermic reactions, under normal atmospheric conditions, for $15 \mathrm{~min}$ milling and 5 minutes idle was used in the study the variable process parameters used for the mechanical alloying as shown in Table 2.

At every five hours of milling $(0 \mathrm{~h}, 5 \mathrm{~h}, 10 \mathrm{~h}, 15 \mathrm{~h}, 20 \mathrm{~h})$ the powders were taken out and changes in the constitutions of phases through X-ray diffraction (XRD) with a scan speed rate of $10^{\circ} /$ min under target mode as $\mathrm{Cu} \mathrm{K \alpha}$, with the current and scanning voltage were used at $40 \mathrm{~mA}$ and $40 \mathrm{kV}$ respectively. The microstructural evaluation of particles was analyzed using scanning electron microscopy (SEM). The crystallite size $(D)$ and lattice strain $(\boldsymbol{\varepsilon})$ were measured from diffraction line analysis using the Debye Scherrer equation in 1 and 2 followed by X'- Pert high score plus software. Where $\lambda$ is denoted as X-ray wavelength, $\beta$ is denoted as the full width at half maximum (FWHM), $\theta$ is denoted as Bragg angle [14].

$$
\begin{aligned}
& \text { Crystallite size }(D)=\frac{0.9 \lambda}{\beta \cos \theta} \\
& \text { Lattice strain }(\varepsilon)=\frac{\beta \cot \theta}{4} .
\end{aligned}
$$




\subsection{Taguchi technique}

The Taguchi technique is an influential design of an experimental tool for obtaining the data in a controlled manner for the design of a high sound quality approach. By conducting the robust design of experiments, the number of experiments was minimized through the Taguchi method. The main aim of the method is to make a good quality product at a lower cost with saving time and resources for the manufacturing industry. The design of experiments is affordable based on the combination of levels and factors, which will reduce the repeated number of experiments and save resources. The optimized milling process parameters of the ferritic ODS steel through MA followed by the Taguchi technique in controlled parameters were used in this study of milling time and milling speed. The optimum process parameters, the design of control factors, and levels are shown in Table 2. The practical consequences such as crystallite size were examined through the $\mathrm{S} / \mathrm{N}$ ratio (signal to noise ratio), and the smaller is better was used in the present study. The 'Signal' term indicates the preferred

Table 2. Design of control factors and levels for Taguchi analysis.

\begin{tabular}{llll}
\hline & \multicolumn{3}{c}{ Control Factors } \\
\cline { 2 - 3 } Level & Milling Time (hrs) & Milling & Speed (rpm) \\
\hline I & 10 & 200 \\
II & 15 & 250 \\
III & 20 & 300 \\
\hline
\end{tabular}

responses, and the 'Noise' term indicates the undesirable values from uncontrollable factors. To compute the smaller is better, the $\mathrm{S} / \mathrm{N}$ ratio in equation (3) is used and given below [15-17]. In equation (3), ' $n$ ' is denoted as replication number, and ' $y$ ' is denoted as observed response significance.

$$
\frac{S}{N}=-10 \log \frac{1}{n}\left(\Sigma y^{2}\right)
$$

\section{Results and discussion}

The experiments were performed based on the $\mathrm{L}_{9}$ orthogonal array, and the crystallite size results acquired for different proportions of process parameters are shown in Table 3 . And for measuring the quality characteristics, the experimental results were changed into $\mathrm{S} / \mathrm{N}$ ratios using MINITAB 17.0.

The statistical Taguchi analysis was performed using the Signal to Noise Ratios when more minor is better based on the quality characteristics in equation (3) for the observed response value (crystallite size) as shown in Table 4. The rank order columns defined the delta values when varying the milling process parameters from level 1 , level $2 \&$ level 3 . The more considerable delta value gives the better influencing factor on the crystallite size from level 1 to 3 . It is evident that based on the grade result as shown in Table 4, the most significant influential factor is milling speed on the crystallite size followed by the milling time. In addition to that collective response graph (crystallite size) is shown in Figure 2. It was observed

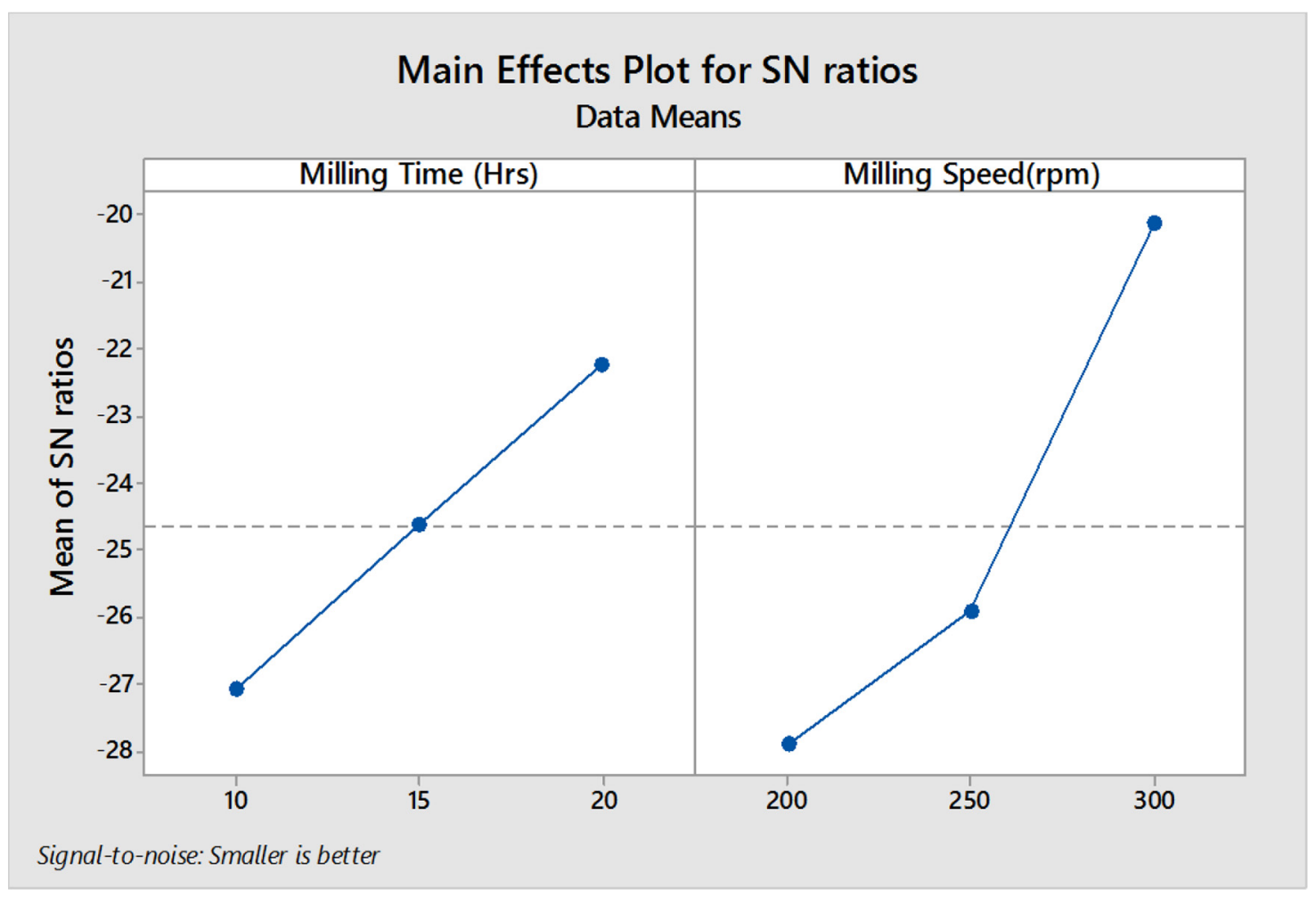

Fig. 2. Main effects plot for the signal to noise ratio. 
Table 3. Design of $\mathrm{L}_{9}$ orthogonal array used for Taguchi analysis and calculated values of crystallite size and lattice strain.

\begin{tabular}{llllll}
\hline \multirow{2}{*}{ No of trails ID } & \multicolumn{2}{c}{ Process parameters } & Crystallite size & Lattice strain & S/N Ratios \\
\cline { 2 - 6 } & Milling Time (hrs) & Milling Speed (rpm) & $\mathrm{nm}$ & $\%$ & - \\
\hline 1 & 10 & 200 & 40 & 0.80 & -29.0326 \\
2 & 10 & 250 & 34 & 0.92 & -27.6225 \\
3 & 10 & 300 & 24 & 1.11 & -24.6032 \\
4 & 15 & 200 & 36 & 1.24 & -28.1209 \\
5 & 15 & 250 & 32 & 1.31 & -27.1000 \\
6 & 15 & 300 & 30 & 1.49 & -18.6398 \\
7 & 20 & 200 & 20 & 1.58 & -26.5442 \\
8 & 20 & 250 & 10 & 1.67 & -23.0405 \\
9 & 20 & 300 & & 1.69 & -17.1120 \\
\hline
\end{tabular}

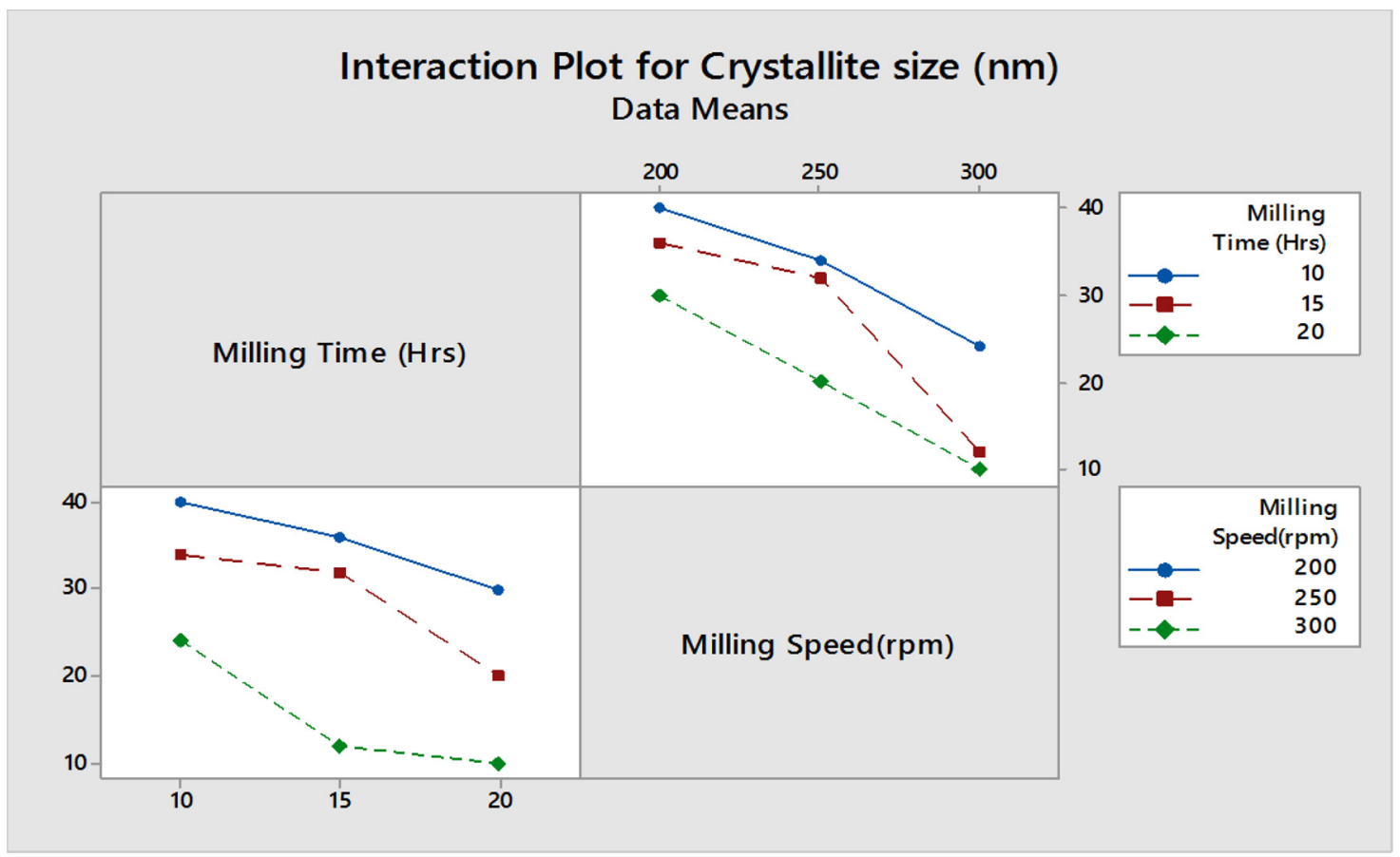

Fig. 3. Interaction plot for crystallite size.

Table 4. Crystallite size - response table for $\mathrm{S} / \mathrm{N}$ ratios when smaller is better.

\begin{tabular}{lll}
\hline Level & Milling time $(\mathrm{h})$ & Milling speed $(\mathrm{rpm})$ \\
\hline $\mathbf{1}$ & -30.09 & -30.90 \\
$\mathbf{2}$ & -27.60 & -28.92 \\
$\mathbf{3}$ & -25.19 & -23.06 \\
Delta & 4.90 & 7.84 \\
Rank & 2 & 1 \\
\hline
\end{tabular}

that the appropriate milling process parameters for attaining nanocrystalline size minimize the response value with a milling speed of $300 \mathrm{rpm}$ and the milling time $20 \mathrm{~h}$. It was concluded that for MA of ferritic ODS steel to fabricate the nanocrystalline size, the suggested milling process parameters of the higher grade of milling speed, the lower grade of the milling time were obtained in the present study.

\subsection{Examination of linear regression analysis and ANOVA}

In the present study, obtain the coefficient of correlation regression and response of the ferritic ODS steel, the analysis of linear regression equation was used. The crystallite size value of the regression coefficient, $\mathrm{R}^{2}$ $(95.7 \%)$, is in good quality conformity with the accustomed $R^{2}(91.3 \%)$ values. The obtained result of the crystallite size regression equation is shown in equation (4). 
Table 5. ANOVA analysis for crystallite size.

\begin{tabular}{llllllll}
\hline \multicolumn{2}{c}{ Milling parameters } & & & \multicolumn{5}{c}{ Crystallite size } \\
\cline { 5 - 7 } Factors & DF & & SS & MS & F-Value & $P$-Value & PC\% \\
\hline Milling Time (hrs) & 2 & & 240.89 & 120.444 & 12.32 & 0.020 & 26.699 \\
Milling Speed (rpm) & 2 & & 622.22 & 311.111 & 31.82 & 0.003 & 68.965 \\
Error & 2 & & 39.11 & 19.555 & - & - & 4.334 \\
Total & 6 & & 902.22 & - & - & - & 100 \\
\hline
\end{tabular}

Note: PC, Percentage of contribution; P, Probability of significance at 5\%; DF, Degree of freedom; MS, mean squared deviation; $F$, Fisher's F ratio; SS, sum of squared deviation.

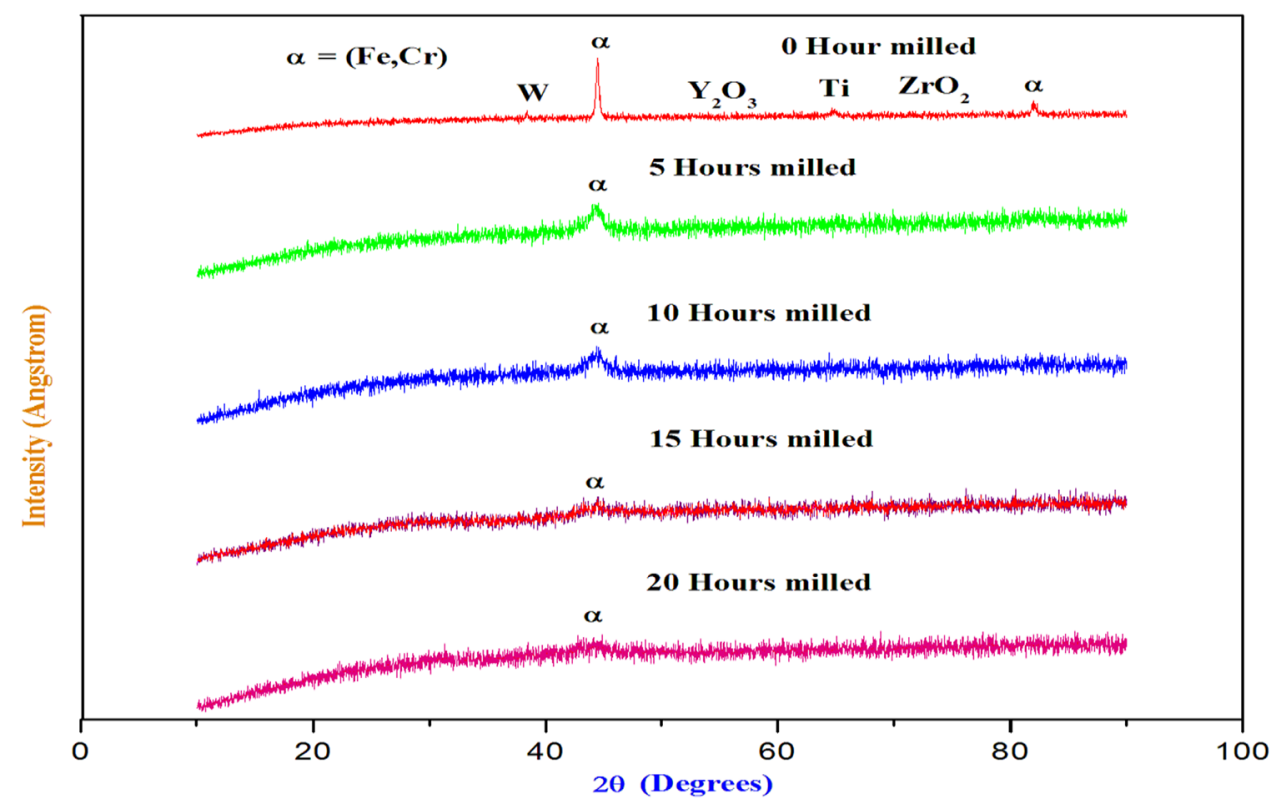

Fig. 4. XRD plot at different milling time intervals $(0 \mathrm{~h}, 5 \mathrm{~h}, 10 \mathrm{~h}, 15 \mathrm{~h}, 20 \mathrm{~h})$.

Table 6. Best Parameters results of confirmation test for crystallite size.

\begin{tabular}{lllll}
\hline $\begin{array}{c}\text { Optimized milling process parameters } \\
\text { Milling Time (hrs) }\end{array}$ & $\begin{array}{l}\text { Experimental value } \\
\text { Crystallite size }(\mathrm{nm})\end{array}$ & $\begin{array}{l}\text { Predicted value } \\
\text { Crystallite size }(\mathrm{nm})\end{array}$ & $\begin{array}{l}\text { Percentage of error } \\
\mathbf{\%}\end{array}$ \\
\hline 20 & 10 & 10.1 & 1 \\
\hline
\end{tabular}

The regression equation for crystallite size is,

$$
\begin{gathered}
95.44-1.267 \text { Milling Time (hrs) } \\
-0.2000 \text { Milling Speed (rpm) } \\
=\text { Crystallite size }(\mathrm{nm}) .
\end{gathered}
$$

To acquire the optimum milling process parameters of the ODS ferritic alloy $\left(\left(430 \mathrm{~L}+0.3 \mathrm{Y}_{2} \mathrm{O}_{3}+0.5 \mathrm{ZrO}_{2}+0.1\right.\right.$ $\mathrm{Ti}+1 \mathrm{~W})$ wt.\%), Yttrium (0.3 wt.\%), Zirconium (0.5 wt.\%), Titanium (0.1 wt.\%), and Tungsten (1 wt.\%), the investigation of milling speed and milling time was used in the present study. Based on response Table 4 and the response diagram of the $\mathrm{S} / \mathrm{N}$ ratio (Fig. 2), the optimized milling parameters of milling speed $(300 \mathrm{rpm})$ and milling time
$(20 \mathrm{~h})$ were noted in the study. The ANOVA method was performed by the MINITAB 17.0. Based on the ANOVA as shown in Table 5 , the $p$-value was acknowledged as less than 0.05 , and it is shown that the milling parameters has enormously significant at a $95 \%$ assurance level. The PC is shown in Table 5 in the last column, which revealed each milling process parameter's scheming on the crystallite size. Since the ANOVA table, it was eminent that the milling speed and milling time as $300 \mathrm{rpm}, 20 \mathrm{~h}$ were the foremost influencing factors. It was observed that the ANOVA and S/N ratio results showed were closely nearer to each other. The PC results were noted as milling speed (68.965\%), milling time $(26.699 \%)$ for crystallite size of the ODS ferritic alloy. 


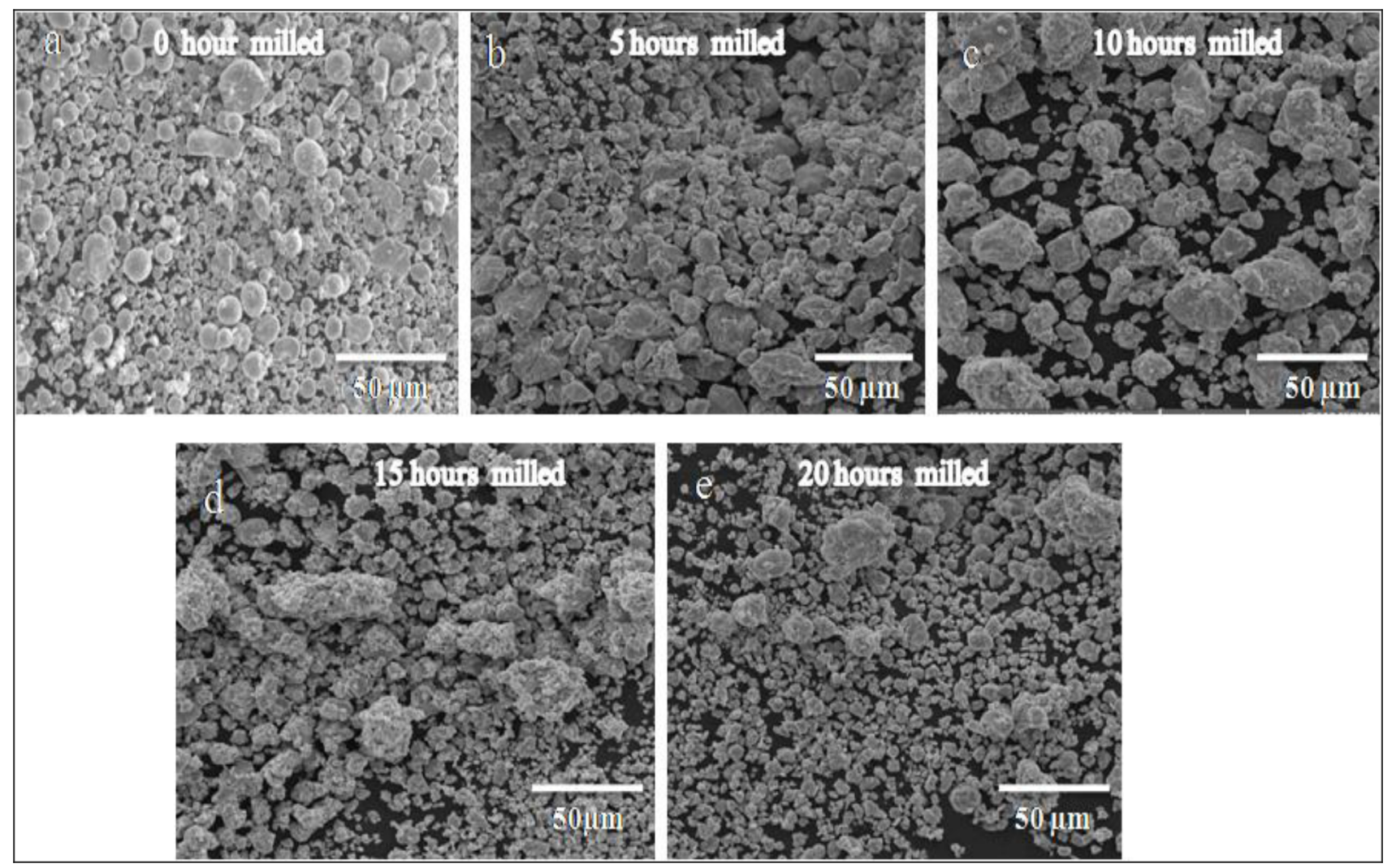

Fig. 5. SEM morphology of milled powders at different time intervals (a) $0 \mathrm{~h}$, (b) $5 \mathrm{~h}$, (c) $10 \mathrm{~h}$, (d) $15 \mathrm{~h}$, (e) $20 \mathrm{~h}$.

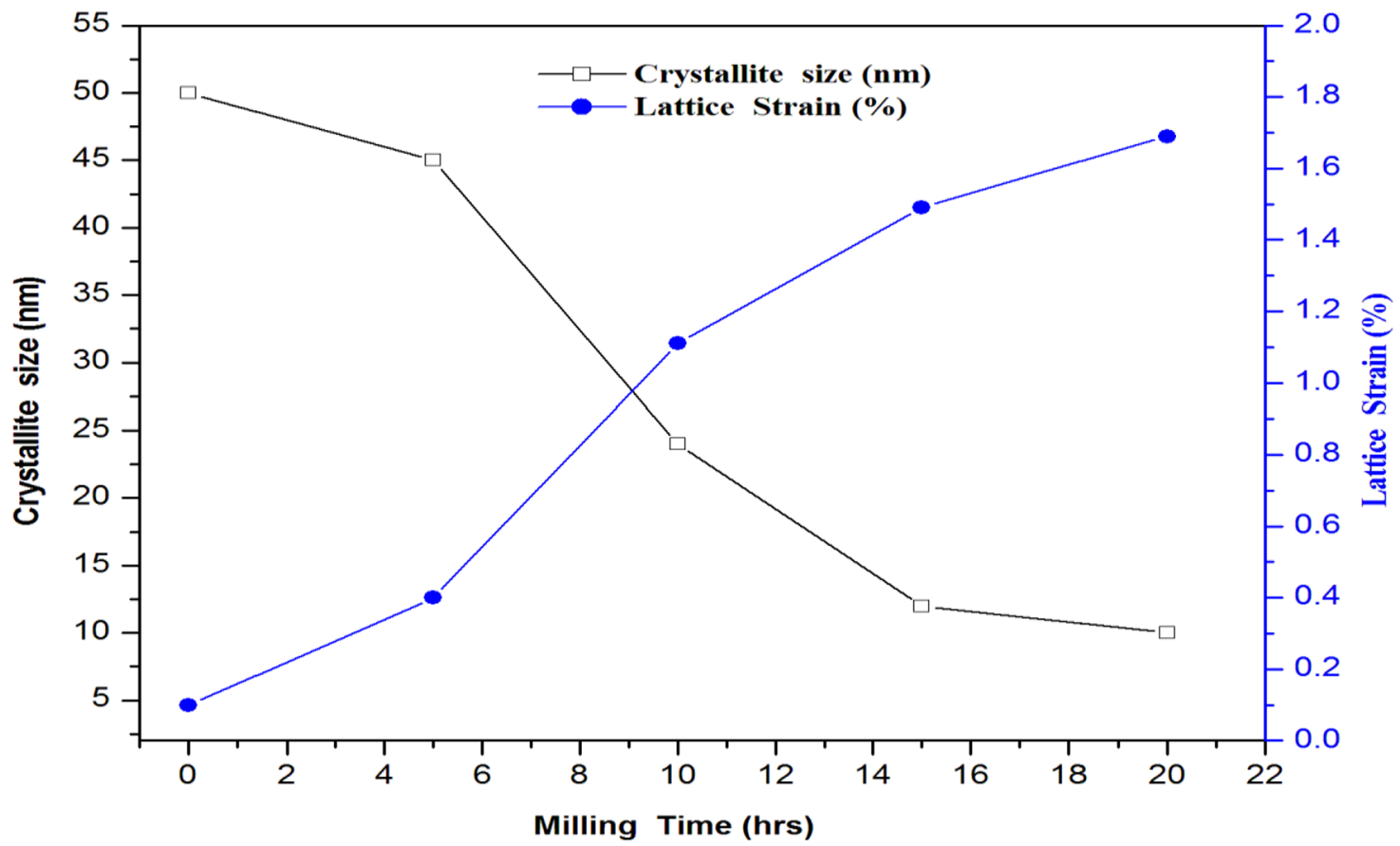

Fig. 6. Crystallite size and Lattice strain concerning different milling times at $300 \mathrm{rpm}$. 


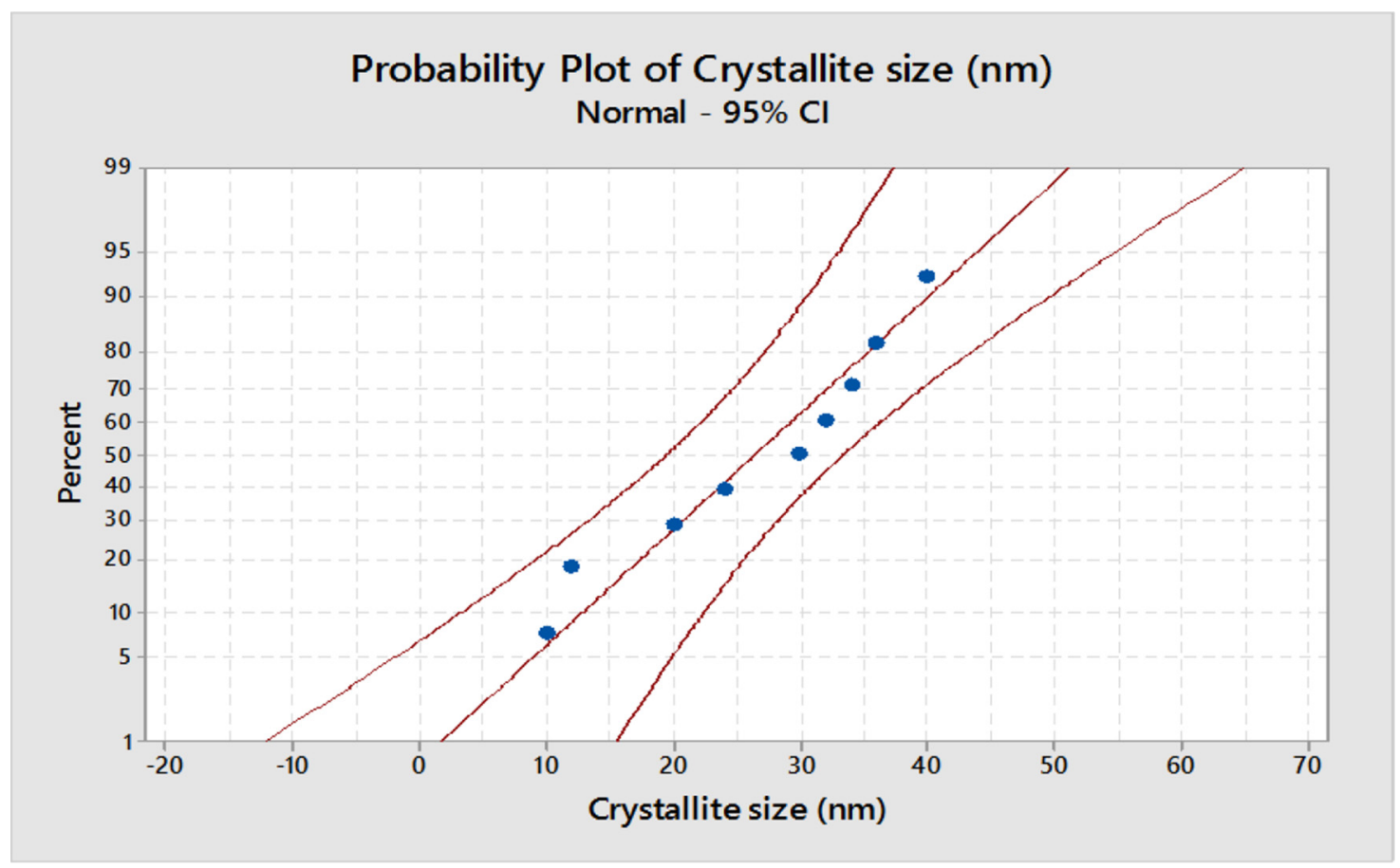

Fig. 7. Probability plot of crystallite size.

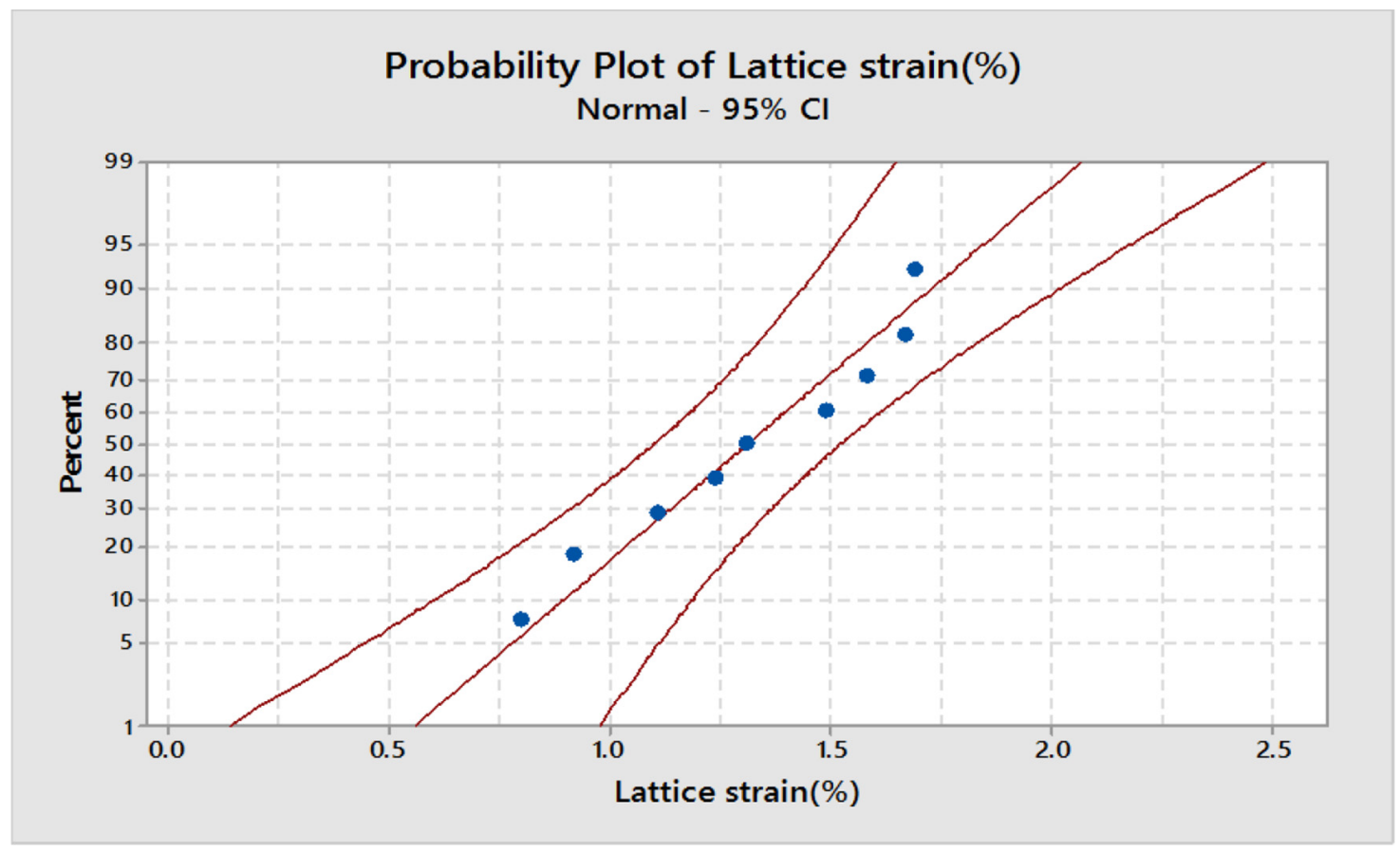

Fig. 8. Probability plot of lattice strain.

\subsection{Interaction plot for crystallite size}

In the interaction plot of the crystallite size as shown in Figure 3, it was observed that higher milling speed resulted in the drastic reduction in crystallite size due to high impact force collision between the ball and powders. Whereas the lower milling speeds could be the result of the lower reduction in crystallite size was observed because of the lesser impact force collision. The milling time increases the crystallite size reduction was noted. The milling time between $15 \mathrm{~h}$ and $20 \mathrm{~h}$ almost saturates crystallite size reduction was observed at $300 \mathrm{rpm}$ whereas another milling speed shows more deviation in the crystallite size reduction. It shows that the milling speed is the major 
Table 7. Comparison of milling process parameters than existing processing of the alloys.

\begin{tabular}{|c|c|c|c|c|c|}
\hline S. no & Alloys (In wt \%.) & $\begin{array}{l}\text { Powder Processing } \\
\text { route }\end{array}$ & $\begin{array}{l}\text { Milling process } \\
\text { parameters }\end{array}$ & $\begin{array}{l}\text { Crystallite } \\
\text { size }(\mathrm{nm})\end{array}$ & References \\
\hline 1 & $\begin{array}{l}9 \mathrm{Cr} \text { ferritic ODS } \\
\text { steel contains } \mathrm{W}, \\
\mathrm{V}, \mathrm{Y}_{2} \mathrm{O}_{3}\end{array}$ & Planetary ball mill & $\begin{array}{l}\text { Speed-300 rpm, } \\
\text { Milling time }-36 \mathrm{hrs,} \\
\text { ball diameter- } 5 \mathrm{~mm} \text {, } \\
\text { Ball to powder } \\
\text { ratio- } 3.4: 1\end{array}$ & 24 & {$[20]$} \\
\hline 3 & $\begin{array}{l}15 \mathrm{Cr}-0.3 \mathrm{Ti}-0.3 \mathrm{Zr} \\
-4.5 \mathrm{Al}-0.3 \mathrm{Y}_{2} \mathrm{O}_{3}\end{array}$ & $\begin{array}{l}\text { High energy } \\
\text { planetary ball mill }\end{array}$ & $\begin{array}{l}\text { Speed-260 rpm, } \\
\text { Milling time }-50 \text { hrs, } \\
\text { Ball to powder ratio- } \\
\text { 10:1 }\end{array}$ & 16.5 & {$[14]$} \\
\hline 5 & $14 \mathrm{Cr}-3 \mathrm{~W}-0.3 \mathrm{Y}_{2} \mathrm{O}_{3}$ & $\begin{array}{l}\text { High energy ball } \\
\text { mill }\end{array}$ & $\begin{array}{l}\text { Speed- } 250 \mathrm{rpm} \text {, } \\
\text { Milling time }-72 \mathrm{hrs} \text {, } \\
\text { Ball to powder } \\
\text { ratio-10:1 }\end{array}$ & 8 & {$[22]$} \\
\hline 6 & $\begin{array}{l}17 \mathrm{Cr} \\
+0.3 \mathrm{Y}_{2} \mathrm{O}_{3}+0.5 \\
\mathrm{ZrO}_{2}+0.1 \mathrm{Ti}+1 \mathrm{~W}\end{array}$ & $\begin{array}{l}\text { High energy } \\
\text { Planetary ball mill }\end{array}$ & $\begin{array}{l}\text { Speed- } 300 \mathrm{rpm}, \\
\text { Milling time }-20 \mathrm{hrs}, \\
\text { ball diameter- } 10 \mathrm{~mm} \text {, } \\
\text { Ball to powder } \\
\text { ratio-10:1 }\end{array}$ & 10 & $\begin{array}{l}\text { Present } \\
\text { work }\end{array}$ \\
\hline
\end{tabular}

influencing factor followed by the milling time. The XRD plot indicates the phase evolution of ferritic ODS steel shown in Figure 4 at different time intervals such as 0 h, 5 h, $10 \mathrm{~h}, 15 \mathrm{~h}, 20 \mathrm{~h}$, and $300 \mathrm{rpm}$, respectively. The XRD pattern of 0hour milled powders noted the sharp peaks and indicated several peaks such as Tungsten, Titanium, Yttrium oxide, Zirconium oxide. The milling time increases the intensity of Tungsten, Titanium, Yttrium oxide, and Zirconium oxide peaks were disappeared after the 5 hours of milling. It shows the ferritic ODS steel alloy formation and reduction in crystallite size.

Further milling time increases about $10 \mathrm{~h}$, the peak broadening and the single-phase structure was noted. The milling time of about $15-20 \mathrm{~h}$ shows more peak broadening, and also saturation in crystallite size reduction was observed, as shown in Figure 6. Finally, at the end of $20 \mathrm{~h}$, milled powders completely single $\alpha$-phase BCC structure were observed and in XRD pattern demonstrating the complete solid solution formation of the alloy [18]. When an equilibrium balance is conserved between the cold welding and fracturing of powder particles, the alloying has happened between the powder particles. Figure 6 indicates as the milling time increases, the decrease in crystallite size reduction was noted with an increase in lattice strain of the alloy. During MA, the broadening of the XRD peak is because of the refinement of crystallite size and lattice strain influence in the powder particles at the mechanical ball milling. This drastically decreases the crystallite size at the earlier stages of milling hours and is finally reduced to $10 \mathrm{~nm}$ at the end of $20 \mathrm{hrs}$ milling at $300 \mathrm{rpm}$ in the present alloy. Figure $5 \mathrm{a}-\mathrm{e}$ demonstrates the morphology of milled powders at different milling times was evaluated using scanning electron microscopy (SEM). Figure 5a indicates the powder morphology of initial powders $(0 \mathrm{~h})$ is spherical. The milling time increases the powder particles demonstrate the impact collision energy, which would result in the observation of particle refinement. From Figure 5b and c, after $5-10 \mathrm{~h}$ of milled powders was showed an irregular shape. This is because impact forces originate the collision of powder-ball-vial during the MA. These impact forces were refining the structure of the alloy as a result of influencing great plastic deformation. After $15-20 \mathrm{~h}$ of milled powders, grain refinement starts to reach the steady-state as shown in Figure $5 \mathrm{~d}$ and e. After $20 \mathrm{~h}$ of milled powders, there is no much deviation in the crystallite size of the alloy.

Finally, the interaction plot concluded that the optimized milling speed parameter of $300 \mathrm{rpm}$ is a major influencing factor in obtaining nanocrystalline size followed by $20 \mathrm{~h}$ of milling time compared to other parameters [19].

\subsection{Probability plot of crystallite size and lattice strain}

The probability plot utility was plotted between the response value of crystallite size and lattice strain in the $\mathrm{X}$-axis, and the percent in $\mathrm{Y}$-axis were shown in Figures 7 and 8 correspondingly. It was noted that the response 
values such as the crystallite size and lattice strain points were fitted within the central line as desired by the central limit theorem.

\subsection{Confirmation test}

The confirmation test was conceded based on the optimized milling progression parameters, as shown in Table 6 . The crystallite size was calculated from the regression equation, and this result was compared to experimental values. It was found that both results are almost nearer to each other with the slightest amount error of $\pm 1 \%$. The practical and regression equation consequences equally are good quality coincidences using the Taguchi approach technique.

The different milling process parameters and the powder processing route are compared with the existing processing of the alloys, as shown in Table 7 . It was noted that slow milling speed takes longer to obtain the nanocrystalline size; moreover, the inhomogeneous grain distribution was observed. Because of the longer milling time result, high impurity inclusions are presented in the microstructure, and high energy is also required to obtain the solid solution. Moreover, the longer milling time could produce a higher lattice microstrain with residual stresses accumulated in the milled powders, which cause inhibition of binding energy during the consolidation of the powders. Therefore, optimized milling parameters of milling speed $(300 \mathrm{rpm})$ and milling time $(20 \mathrm{~h})$ followed by a high energy planetary ball milling process were observed with better results than the existing process. Moreover, the optimized processing route can be produced with cost savings and less time consuming to obtain the nanocrystalline powders than the existing process.

\section{Conclusion}

The nanocrystalline of ferritic ODS steel alloy $\left(430 \mathrm{~L}+0.3 \mathrm{Y}_{2} \mathrm{O}_{3}+0.5 \mathrm{ZrO}_{2}+0.1 \mathrm{Ti}+1 \mathrm{~W}\right)$ wt. $\%$ powder has been successfully incorporated through high energy planetary ball milling followed by a mechanical alloying route. Based on the design of experiments and the Taguchi technique followed by ANOVA, the optimized milling parameters of milling speed at $300 \mathrm{rpm}$ and milling time of $20 \mathrm{~h}$ were identified to obtain the nanocrystallite size of the alloy. The nanocrystallite size of ferritic ODS steel alloy was significantly reduced to $10 \mathrm{~nm}$ through high-energy planetary ball milling after 20hours with a milling speed of $300 \mathrm{rpm}$. The XRD analysis confirmed the complete solid solution of the alloy at $20 \mathrm{~h}$ of ball milling. And also, the particle size reduction was observed through SEM analysis. Based on the optimization technique and the characterization outcome, high-energy planetary ball milling is the best method to produce nanopowders with a homogeneous distribution of reinforcements.

\section{References}

1. A. García-Junceda, E. Macía, D. Garbiec, M. Serrano, J.M. Torralba, M. Campos, Effect of small variations in $\mathrm{Zr}$ content on the microstructure and properties of ferritic ODS steels consolidated by SPS, Metals 10, 348 (2020)
2. N.Y. Iwata, A. Kimura, M. Fujiwara, N. Kawashima, Effect of milling on morphological and microstructural properties of powder particles for high-Cr oxide dispersion strengthened ferritic steels, J. Nucl. Mater. 367, 191-195 (2007)

3. D.P. Doan, T.B. Tran, V.A. Nguyen, A.T. Phan, Microstructural evolution and some mechanical properties of nanosized yttrium oxide dispersion strengthened $13 \mathrm{Cr}$ steel, Adv. Natl. Sci.: Nanosci. Nanotechnol. 1, 035009 (2010)

4. A. Meharwal, M. Kumar, S. Karak, J.D. Majumdar, I. Manna, High temperature oxidation study of nano- $\mathrm{Y}_{2} \mathrm{O}_{3}$ dispersed ferritic alloys synthesized by mechanical alloying and sintering, Metall. Mater. Trans. A 51, 5257-5267 (2020)

5. S. Noh, B.K. Choi, C.H. Han, K.B. Kim, S.H. Kang, Y.B. Chun, T.K. Kim, Effect of Mechanical Alloying and Hot Consolidation Processes on the Microstructure and Mechanical Properties of ODS Steels (2013)

6. S. Cao, Z. Zhou, Microstructure and mechanical properties of an ODS ferritic steel with very low Cr content, J. Nucl. Mater. 551, 152971 (2021)

7. R. Shashanka, D. Chaira, Optimization of milling parameters for the synthesis of nano-structured duplex and ferritic stainless steel powders by high energy planetary milling, Powder Technol. 278, 35-45 (2015)

8. E. Macía, A. García-Junceda, M. Serrano, S. Hong, M. Campos, Effect of mechanical alloying on the microstructural evolution of a ferritic ODS steel with (Y-Ti-Al-Zr) addition processed by Spark Plasma Sintering (SPS), Nucl. Eng. Technol. (2021)

9. J. Harringa, B. Cook, B. Beaudry, Effects of vial shape on the rate of mechanical alloying in Si 80 Ge 20, J. Mater. Sci. 27, 801-804 (1992)

10. M. Staltsov, I. Chernov, I. Bogachev, B. Kalin, E. Olevsky, L. Lebedeva, A. Nikitina, Optimization of mechanical alloying and spark-plasma sintering regimes to obtain ferritemartensitic ODS steel, Nucl. Mater. Energy 9, 360-366 (2016)

11. C. Suryanarayana, Does a disordered $\gamma$-TiAl phase exist in mechanically alloyed TiAl powders? Intermetallics $\mathbf{3}$, 153-160 (1995)

12. C. Suryanarayana, Mechanical alloying and milling, Prog. Mater. Sci. 46, 1-184 (2001)

13. C. Suryanarayana, E. Ivanov, R. Noufi, M. Contreras, J. Moore, Phase selection in a mechanically alloyed $\mathrm{Cu}_{20} 1_{3}$; In-Ga-Se powder mixture, J. Mater. Res. 14, 377-383 (1999)

14. H. Xu, Z. Lu, C. Jia, D. Feng, C. Liu, Influence of mechanical alloying time on morphology and properties of $15 \mathrm{Cr}-\mathrm{ODS}$ steel powders, High Temp. Mater. Process. 35, 473-477 (2016)

15. S. Kumar, M.R. Ahmed, M. Lokesha, L. Manjunath, Investigation of machinability characteristics on C45 steel with cryogenically treated M2 HSS tool using statistical technique, Int. J. Simul. Multidiscipl. Des. Optim. 10, A5 (2019)

16. A. Altin, A comparative study on optimization of machining parameters by turning aerospace materials according to Taguchi method, Int. J. Simul. Multidiscipl. Des. Optim. 8, A1 (2017)

17. G. Dharmalingam, R. Mariappan, M.A. Prasad, Optimization of wear process parameters on 16-Cr Ferritic ODS steel through Taguchi approach, Mater. Today: Proc. 23, 583-589 (2020)

18. M.S. Saravanan, K. Sivaprasad, S.K. Babu, P. Susila, B. Murty, Synthesis and characterization of CNT reinforced AA4032 nanocomposites by high energy ball milling, AIP Conf. Proc. 82-87 (2010) 
19. A. Pandey, K. Jayasankar, P. Parida, M. Debata, B. Mishra, S. Saroja, Optimization of milling parameters, processing and characterization of nano-crystalline oxide dispersion strengthened ferritic steel, Powder Technol. 262, 162-169 (2014)

20. J. Fu, J. Brouwer, I. Richardson, M. Hermans, Effect of mechanical alloying and spark plasma sintering on the microstructure and mechanical properties of ODS Eurofer, Mater. Des. 177, 107849 (2019)
21. R. DiDomizio, S. Huang, L. Dial, J. Ilavsky, M. Larsen, An assessment of milling time on the structure and properties of a nanostructured ferritic alloy (NFA), Metall. Mater. Trans. A 45, 5409-5418 (2014)

22. M. Stanciulescu, P. Carlan, M. Mihalache, M. Abrudeanu, Optimisation of the mechanical alloying process for ODS ferritic steels for generation IV reactors application, Int. Nucl. Inf. Syst. 48, 236-242 (2016)

Cite this article as: Ganesan Dharmalingam, Murali Arun Prasad, Sachin Salunkhe, Optimization of milling speed and time in mechanical alloying of ferritic ODS steel through taguchi technique, Int. J. Simul. Multidisci. Des. Optim. 12, 25 (2021) 